\title{
Language Representation of Covid-19 Report on CNN Indonesia Online Media and its Utilization as a Critical Reading Enrichment Book
}

\author{
Sarimagfirah Rahman ${ }^{1}$, Muhammad Saleh ${ }^{1}$, Idawati ${ }^{1}$ \\ Corresponding Email: sarimagfirah98@gmail.com
}

${ }^{1}$ Language Education Study Program, Postgraduate Makassar State University, Indonesia

Received: December 19, $2021 \quad$ Received in Revised: January 14, $2022 \quad$ Accepted: January 23, 2022

\begin{abstract}
This study aims to describe the form and form of linguistic representation in the CNN Indonesia news text by using social change analysis from Norman Fairclough. The focus of this research is text analysis, text production, and sociocultural analysis with data in the form of grammatical features. This research is a discourse analysis study in the form of critical discourse analysis (AWK). The data source of this research is CNN Indonesia online media which contains words, phrases, clauses, and sentences. The research data was obtained by using documentation, reading, and note-taking techniques. The results show that there are grammatical features which include: (1) modality, (2) negation, (3) sentence mode, (4) transitivity, (5) personal pronouns, and (6) passivity which represents the form of linguistic representation through power in in the news text. Judging from the production of the text, it is shown that the producer of the text in presenting the news cannot be separated from the aspect of domination and power, either power or domination by groups or individuals. In addition, the power in the text serves to strengthen the position of a subject in the text so that the reader is focused on the discourse conveyed by the author of the text. Furthermore, as an implication of the research results, a critical reading enrichment book was compiled.
\end{abstract}

\section{Keywords: Language Representation, Critical Discourse Analysis, News Text, CNN Indonesia Online Media, Grammatical Features}

\section{Introduction}

The era of society 5.0 greatly influenced the development of science, communication and information. In this era so easily an information can be obtained. This happens because we are in a digital era that is developing very rapidly. Currently, information is quickly and easily accessible via online media. However, due to this convenience, we as readers must become readers who have a critical nature with what we read, in order to become a critical reader, one must be more careful and observant in choosing and sorting out a news and information encountered so that it does not become a reader. easy to provoke and influence.

One of the functions of mass media is to serve as a forum for delivering certain discourses to the public (Iosifidis, 2011; Schultz, 2000). This is because, the form of discourse in the form of conversations, texts and others whose forms are arranged in a structured manner so that they reflect certain ideological practices. Ideology is formed from the dominant party to legitimize and produce its dominance by using a scheme that will make the wider audience not aware of the dominance of the dominant party, so that the audience will accept the domination as it is.

The mass media often use language that is not in accordance with reality or events that will later be notified to the public. The reader's understanding of the reality or event is in accordance with the text presented by the mass media. If we refer to the point of view of critical discourse, 
the media is not included in an objective and neutral form, discourses that discuss reality will be full of interests and ideologies from the dominant group.

This is in line with Eriyanto's statement (2009) which reveals that because texts, conversations, and others are a manifestation of the reflection and practice of certain ideologies. A reader must understand and know more deeply how and for what a text is produced and created, so that the reader becomes a critical reader. When the reader understands and understands the meaning of the things presented in the text in more depth, then the reader will know that it turns out that in the text there are certain motives and ideologies that are deliberately hidden in the text. The motives and ideologies in question include persuading, persuading, influencing, and refuting. The same thing was also stated (Sultan, 2018) that critical reading is a method of reading that is carried out in a deeper way in order to better understand and know the information contained in the reading, whether the information is hidden in the text, as well as explicit information from the text.

The presence of critical discourse analysis is another option for the deadlock of text analysis in the media, which has always been dominated by content analysis with constructivist and positivist views. With the presence of critical discourse analysis, this can reveal the wrong use of injustice, ideology, domination, and power that is made and carried out opaquely using news texts. In addition, we can also find out why the text or message was produced and presented, Rakhmat (in Zakaria 2019). Not only that, critical discourse analysis is also not seen as a study of language alone, but is associated with the context of language which is the medium or device that will be used with the intention of certain practices and certain goals, including ideological practices. Although in the discourse analysis actually uses the text to be analyzed, the analysis of language in this context is not the same as the study of language in understanding traditional linguistics. Then the language is connected to the context not only to explain the linguistic aspect. That is, language in that context is used for certain practices and purposes.

According to (Sobur 2006), discourse theory understands that an event occurs as well as the formation of a statement or sentence. The sentence can be revealed not only because someone formed the sentence with a certain subjective interest or motivation, but the sentence can only be meaningful and formed from a number of grammatical rules against the will of the sentence maker. The text is not an empty space in which it is only limited to meaning, but the text is a battle space between one group against another. In a critical perspective, discourse analysis focuses on the forces that take place in the process of reproducing meaning and the process of producing meaning, because it is believed that language is not a neutral medium, but as a representative that functions to create certain discourse themes, certain strategies, or certain subjects in it (Eriyanto, 2009).

Based on the previous explanation, it appears that the most important discussion in critical discourse analysis is to reveal how inequality in practice is also dominated, opposed and reproduced by spoken texts or written texts in the form of social and political contexts. One of the concepts of critical discourse analysis is to dismantle and see the political ideology that exists in the media. This is an urgency because critical discourse in the text is guided and believed to be a manifestation of the reflection of certain ideologies and certain ideological practices. In its use, critical discourse analysis is often used to analyze power, political issues, gender, hegomony, and ideology in the mass media.

Media is the main source for finding information and getting news (Kalogeropoulos et al., 2019; Brossard, 2013).

The information and news found are so easily and quickly accessed via a computer or device. Currently, the role of mass media is very vital in providing information to its readers, this can 
influence readers with the media coverage. If this continues to happen, it will become a crucial problem, because concluding something obtained with minimal or incomplete information will lead to wrong or erroneous conclusions. Mass media expertise in presenting news texts will have an impact on readers. This is because the mass media is able to present the impression and judgment of individuals, institutions, and groups through the text of the news presented. It is undeniable that news comes from the ideology of journalists and the media. The choice of diction or sentences used by a journalist in producing a news text is of course not due to mere coincidence, but is the meaning of reality and ideologically.

The outbreak of the Corona virus or Covid-19 has taken the world by storm. This virus originated in China, the city of Wuhan, Hubei Province. Happened since 2019. The Corona virus was originally thought to have originated from animals, namely bats before spreading to other animals before being transmitted to humans. The economy all over the world is experiencing a downturn due to this outbreak. The Indonesian government for the first time announced on March 2, 2020 about two positive cases of Covid-19 patients. Many online media have discussed this outbreak, including CNN Indonesia. CNN Indonesia provides information globally. Cable News Network Indonesia or also known as CNN Indonesia is a news channel owned by Trans Media in collaboration with Turner International, a company owned by CNN. CNN Indonesia was broadcast for the first time since August 17, 2015, and carried out its main launch which took place on December 15, 2015. CNN Indonesia is a news platform that always provides the latest information about Covid-19.

The choice of the online news site CNN Indonesia as the source of research data is due to the fact that the mass media is a mass media that collaborates with international turners, after knowing the methods and strategies used by the mass media in reporting cases, impacts, and everything about Covid-19 so that it will be known how the ideology used by the mass media in influencing public opinion. In addition, the selection of online news sites as data sources is based on the researcher's assumption that online news sites are more accessible to the public than print versions. To reveal how the linguistic representation is displayed on the online news site CNN Indonesia, the researcher considers Norman Fairclough's critical discourse analysis to be the right choice in analyzing the news. This is because Fairclough's critical discourse analysis has good details and is structured or systematic to analyze a text. The researcher will use Fairclough's critical discourse analysis method, using linguistic features, but in this study, the researcher will focus on grammatical features that have ideological contents through linguistic representation. In this study, the researcher chose Norman Fairclough's social change critical discourse analysis as the analytical method. Fairclough's critical discourse analysis is then called Fairclough's critical discourse analysis.

Researchers consider this crucial to be investigated because technological developments are very rapid so that information is very easy to access and obtain, including Covid-19 news, which until now still dominates searches on internet platforms. This can cause problems, if information and news seekers are not observant in sorting, critical to filtering, and responding to the information obtained. The results of the use of the book that will be designed should be able to become reading that can make readers more literate and know what critical reading is about so that they are not easily consumed by hoaxes or other interests in the news text.

The ease with which readers can obtain information from online and print media and from various sources is feared to have a negative effect on readers. If only a reader is not observant in filtering readings and understanding the information he gets. Actually, things like this can be minimized by learning to read critically, because this skill is able to train readers to evaluate texts and analyze texts while reading. Both the text is written and spoken text that is in his life. 
It is undeniable that language will represent an ideology in it, not only consciously of ideas, ideas or thoughts but ideology has properties that can invite and influence other people. It is often found that the instillation of ideology from language speakers to their interlocutors is often encountered. However, by being a critical reader, the reader will not swallow what he reads and hear whole, but will interpret the information received first.

\section{Methods}

This study uses a qualitative descriptive approach which aims to analyze data in the form of words, phrases, clauses and sentences that display linguistic representations in the online news text of CNN Indonesia. This research produces a description of vocabulary features based on the theory of Norman Faircought. The data collection process applied in this research is the referential method. The listening method is a way of obtaining data by listening and understanding carefully the use of language (Mahsun, 2007). Data collection techniques that were also used to complement the listening method included:

The text of the news that will be observed and listened to in the online version and documented. The note-taking technique is an advanced technique after applying the listening method. The note-taking technique is done by writing or recording the data obtained. After being identified and marked, the data is then copied to a data card for in-depth and critical analysis.

The library technique is carried out by means of researchers reading carefully and critically various literatures related to research and main data sources. This study uses the role of the researcher as the main instrument. The data source used is the online news text of CNN Indonesia, while the data card as a research tool is used to record and classify the data that has been marked, and then the data is copied to the data card for analysis. The stages of the data analysis process, after grouping the data, the data is then analyzed using critical discourse analysis techniques. Data analysis techniques are not bound and can be adapted to research needs and research problems. This research is based on a critical approach based on this, then the data analysis carried out in this study consists of:

Words, phrases, clauses, and sentences contained in the news text are identified to find words, phrases, clauses or sentences that display linguistic representations in CNN Indonesia's online media. The data are in the form of words, phrases, clauses, and sentences that display linguistic representations in the online media of CNN Indonesia. The data is then classified by type.

The data, which have been grouped by type, were analyzed using Fairclought critical discourse analysis, to describe in detail the linguistic representation in CNN Indonesia's online media. At this stage. After the data has been analyzed, it is then interpreted and reaffirmed the features of the vocabulary in the online media of CNN Indonesia

\section{Results and Discussion}

In accordance with the analysis of social change from Norman Fairclough. Aspects that are considered in this study are text analysis, text production, and sociocultural analysis with data in the form of grammatical features. The aspects referred to are grammatical features which include: (1) modalities; (2) negation; (3) sentence mode; (4) transitivity; (5) personal pronouns; and (6) passivity.

Based on the analysis that has been done by the researcher, some data are obtained that show the use of grammatical features in the text, while the research findings are as follows:

Modality :

Modality is a classification of propositions according to the denial of possibility or necessity; also the way the speaker expresses his attitude towards a situation in an interpersonal 
communication. Modality is divided into 4 types, namely intentional modality, epistemic modality, dynamic modality, and deontic modality. In the Covid-19 news text, it was found that some vocabulary showed the use of grammatical features of the modality type as in the following data:

(1) Anies said the effort was made to at least suppress the transmission of the corona virus when non-essential activities began to open. He also hopes that with the discourse, there will be no more Jakarta residents who refuse to be vaccinated. (D2.fg.m.int.32)

The description of the context in (data 1) discusses the sanctions for cafes and warteg that receive visitors who have not been vaccinated. Anies stated that the sanctions would at least reduce the spread of the corona virus. The use of the word hope in the text is included in the grammatical features which include intentional modalities which are marked by the form of hope referred to in the text. The word hope shows the modality used to express the speaker's attitude in relation to the event he is expressing. Through the utterances expressed can express wishes, hopes, and requests.

Anies Baswedan hopes that with the discourse that all sectors that were previously closed due to PPKM can open the eyes and ears of the community so that no more people will refuse to be vaccinated. The text also shows the context of the social relationship described between Anies as a representative of the government and the community. Analysis of this relationship in the text is actually very crucial because the influence of unique positions will be revealed in the media that shows the context of society.

(2) Although the vaccination program has been intensified, Muhadjir emphasized that the public still has to comply with health protocols and PPKM rules in order to curb the rate of transmission of Covid-19. (D2.fg.m.epi.24)

The context in (data 2) shows that Indonesia will again receive the moderna type of Covid-19 vaccine. With the vaccine coming back to Indonesia, the Coordinating Minister for Human Development and Culture Muhadjir Effendy re-emphasized that the public must still comply with health protocols and PPKM rules even though they have been vaccinated. The modality used in the text is an epistemic modality in the word must. In that word there is an order for the community to still comply with health protocols and PPKM rules. Epistemic modality relates to the speaker's assessment of the possibility and necessity that something is so or not. This means that certain parties can make decisions about something.

As in the text, although vaccination has been intensified, people still have to comply with health protocols and PPKM rules. This policy was taken because it has gone through an assessment from the government so that they require the public to obey and obey to put the brakes on the rate of transmission of Covid-19 in Indonesia. The linguistic representation that is displayed in the text as a linguistic device hidden behind grammatical linguistic features includes epistemic modalities which are used as a medium to convey their dominance through words must be on the data.

\section{Disclaimer}

Negation is the value of experience expressed in positive sentences. In certain cases, the text generator may express it in negative sentences. such as the following data (3):

(3) Not a few pilgrims who do not use masks. In addition, there is no distance between worshipers when carrying out worship. (D2.fg.pen.42)

The context that the text generator wants to convey is that several mosques in Jakarta hold Friday prayers without a vaccine condition even though Jakarta is still under PPKM level 4 rules. expressed in positive sentences. But actually in this sentence there is manipulation that

Copyright $\odot$ 2022, Journal of Asian Multicultural Research for Social Sciences Study, Under the license CC BY-SA 4.0 
is present in the text generator in the sentence. Referring to the sentence produced by the text producer which will be understood by the reader indirectly, only a few congregants do not wear masks. With this sentence the reader will be manipulated that actually in the Friday prayer activities which are carried out in the midst of PPKM Level 4 which is still ongoing, only a few congregations who come to carry out their Friday prayers are not wearing masks.

But actually the text generator manipulates the reader so that the reader understands what the text producer wants to convey like that, even though if you are more observant in understanding the sentences produced by the text producer, in fact many congregants do not wear masks while in the mosque area while carrying out Friday prayers. This is of course contrary to the rules that apply that religious activities in implementing PPKM must comply with health protocols. A text generator is able to manipulate readers with text produced by using words, phrases, sentences, and sentences in the text. A person is able to dominate or manipulate others with the language used. The text generator on the data shows the linguistic representation through the data.

\section{Sentence Mode}

Sentence mode relates to the way in which the sentence is expressed to the interlocutor. There are three kinds of sentence modes: (1) declarative sentences, (2) interrogative sentences, and (3) imperative sentences. as in the following data (4):

(4) "So, where exactly is the item? In which area? How many are there in that area. So don't just mention it in regions, because Indonesia has hundreds of regions," said the member of the Deputy Chairman of Commission VI DPR RI. (D2.fg.mk.int.44)

In (data 4), the main focus is the transparency of the corona virus vaccine stock due to confusing information in regions in Indonesia regarding the Covid-19 vaccine. This made members of the Deputy Chairman of Commission VI DPR RI to ask about the concerns. The speaker or text producer is able to attract the reader's attention through the interrogative sentence mode. The use of interrogative sentences will create focus on the text. In accordance with the text, the thing that wants to be built through discourse is curiosity about where vaccines are distributed, distributed to which regions and how many. In (data 4), the discourse actually shows a power over the government which in fact is the party who knows these things. The government is represented as an object that is unable to provide certainty and answers regarding issues related to the vaccine in question.

The sentence mode strategy is part of the text-producing effort to guide the reader to find important things in the discourse. The interrogative sentence mode causes the reader to focus on that part of the text. From the point of view of the directive text, the reader's focus on the text does not provide more knowledge. It is only limited to directing the reader to the text to focus on the text.

\section{Transitivity}

Transitivity discusses the grammatical elements that are used systematically to express the relationships between the participants involved in communication situations, actions, circumstances, or events as in the following data:

(6) The chairman of the Gerindra faction of the DKI Jakarta DPRD, Rani Mauliani, criticized the provincial government's move to require Covid-19 vaccinations for traders and visitors to food stalls or warteg, street vendors (PKL), and hawker stalls. In general, Rani admits that she supports that all people are required to get a vaccine to create herd immunity. However, careful consideration is needed if the vaccine is made the main requirement for the community in carrying out their daily activities. (D2.fg.ket.46) 
The description of the context in general describes the sanctions that will be given by the Governor of DKI Jakarta Anies Baswedan against Cafes and Warteg which accept visitors but have not been vaccinated. What Anies has planned has its pros and cons. Including the chairman of the Gerindra faction of the DKI Jakarta DPRD, Rani Mauliani, who is against this. There are grammatical features including transitivity in (data 6), there are 2 clauses in the text, namely criticizing the government's steps and Rani admitting to support. Transitivity is associated with understanding the reality of what is going on. The meaning of a predicate and the nouns associated with the predicate.

The word criticizing is a verb form and the government's step is a noun form that describes the actions or actions used to express the relationship between the participants involved in the criticizing situation as a form of delivery to represent the voices of the lower classes who are restless over government policies. While the second clause, Rani which is a noun and claims to support is a verb form similar to the first clause. However, in this clause, Rani, who acts as the People's Representative Council, is shown as being wishy-washy in the text because after criticizing she then supports it. Even though what Rani supports is actually a positive thing because in general she wants all people to be vaccinated to get herd immunity.

\section{Persona Pronouns}

Personal pronouns are a set of pronouns that represent the grammatical category of the person. The use of this pronoun is related to the relationship between power and solidarity, as shown in data 7 below:

(7) A number of traders and buyers at Pasar Minggu, South Jakarta, unanimously rejected the plan to apply vaccine certificates as a condition for mobility in traditional markets in DKI Jakarta. They considered the vaccine certificate as a requirement to carry out activities in the market too burdensome. (D2.fg.pp.48)

Referring to the context (data 7) describing the rules regarding vaccine requirements for traders and buyers at the Sunday Market. Traders and buyers agree to refuse, the vaccine certificate which is used as a condition to carry out activities at the Sunday Market, this is considered burdensome. Their pronouns in the text show an understanding between the seller and the buyer. This pronoun is used as an effort to show harmonization between the two. Text generators show their power in the text by using their plural person pronouns.

Those who are meant are traders and buyers who produce the text, that both agree and are united to reject the application of vaccine certificates as a condition of mobility in traditional markets. The producer of the text in producing the text is not neutral, this is because the text does not state the reasons why the government as the holder of power imposes the conditions for the vaccine card in the traditional market. The text generator seems to side with traders and buyers about this rejection.

In fact, if viewed in general terms, the government as the holder of the highest authority has reasons that are actually able to prevent transmission and make people who are stubborn vaccines without clear reasons will follow the rules so that the chain of spread and positive communities will be reduced. -This is in the text, the government as the highest power holder does not seem to care about the community. The power used by the text generator is a form of linguistic representation by using language as a tool.

\section{Passive}


Facilitation is action processes that can appear in active or passive sentences. The discussion of active-passive sentences is based on the nature of the relationship or relationship in the subject with the predicate in the sentence, as in data (8).

(8) According to Ani, the two options were given to pursue the target of communal immunity (herd immunity). (D2.fg.pem.52)

The background context (data 8) is the Covid-19 vaccination which will be paid for in 2022 and the government's efforts to accelerate vaccines through the implementation of a vaccination program which is still financed by the state budget. The use of passive sentences in the given word is a grammatical feature including passivation. The basic form of the word "beri" becomes "given" because it gets the affix "di-" and the suffix "an-". The word given experiences a passive voice effect, so actors who give the option of the independent or paid scheme Covid-19 vaccination program in 2022 are eliminated. The actor giving the option is the government not shown in the text. The disappearance of the actor hides behind the passive voice in the text. The discussion of passive sentences is based on the nature of the relationship or relationship in the subject with the predicate in the sentence. If this sentence is active, it will display actors such as, the government provides both options to pursue the target of communal immunity (herd immunity).

The big reason for the omission of actors in the text is the form of lingual power through language. The government had previously canceled the discourse on independent or paid vaccines through the mutual cooperation vaccination program. However, the plan was canceled after reaping the pros and cons in the community, but recently this discourse has been hotly discussed again and will be implemented in 2022. The omission of actors in the text serves to eliminate actors who give back options or choices regarding independent or paid vaccines. A government that initially canceled, then suddenly re-planned it would be considered inconsistent. This results in the omission of actors in the text. Through language representation, the dominant party or text producer is able to hide his presence in the text for various reasons that can benefit the dominant party or the pencil text.

The results of the research will be used as an enrichment book design. Enrichment books are classified as non-text books and have the aim of broadening their horizons, enriching the knowledge and experience of their readers. In contrast to textbooks, enrichment books have unique characteristics. The form of presentation of enrichment books can be varied, either in the form of illustrations, discourse plots, or variations of images. Enrichment books are divided into 3 types, namely: knowledge, skills, and personality enrichment books. However, in this study, the researcher designed a type of knowledge enrichment book.

This book contains discussions on critical discourse analysis, the discourse approach according to Norman Fairclough, and critical reading. Through this enrichment book, researchers not only want to provide reading references on linguistic representation with the Norman Fairclough approach, but also provide guidelines for becoming a critical reader. This critical reading enrichment book is based on the findings and discussion of research. The following contains the contents of the enrichment book and explanations for each chapter. Chapter 1 bRepresentation of language, this section describes the representation of language. In this section, we will explain what linguistic representation is. Chapter 2 Critical Language Studies, in this section will describe critical reading theory and critical discourse analysis. The two theories are the basis for recognizing how linguistic representations are displayed in a text. Chapter 3 Norman Fairclough's Discourse Approach and Its Use in News Texts, this section describes the analysis of news texts in CNN Indonesia's Online Media which represents linguistic representation with Norman Fairclouh's discourse approach. 


\section{Conclusion}

In general, the grammar found in the text on CNN Indonesia is dominated to strengthen the characters in the text. This is a way for the text generator to control and at the same time limit the reader from discovering other things from the discourse other than what the reader must know. One of the main goals in using grammar which represents language as a form of power in the text is to strengthen the position of a subject in the text so that the reader is focused on the discourse conveyed by the producer of the text. Utilization of the results of this study, in the form of making a knowledge enrichment book entitled "Critical Language Studies (Discourse Analysis of Norman Fairclough's Approach in News Text). The parts of this enrichment book prototype include the cover of the book, the form of the book, and the content of the book. The contents of the enrichment book are organized into three parts consisting of: (1) Part 1 contains an explanation of what linguistic representation is; Part 2 contains an explanation of critical reading theory and critical discourse analysis; and (3) Section 3 contains an explanation of the analysis of news texts with the discourse approach of Norman Fairclough on CNN Indonesia online media which is a linguistic representation. The enrichment book compiled by the researcher aims to increase the knowledge or insight of the reader. The book explains the role of critical language studies or critical reading of lingual phenomena in the form of linguistic representations. Therefore, it can be used as critical reading to identify the intent and purpose of a text and the hidden motives in it.

\section{References}

Brossard, D. (2013). New media landscapes and the science information consumer. Proceedings of the National Academy of Sciences, 110(Supplement 3), 14096-14101.

Eriyanto. (2009). Analisis Wacana: Pengantar Analisis Teks Media. Yogyakarta: LKis.

Fairclough, N. (2003). Language and Power. Diterjemahkan Oleh Indah Rohmani dengan judul Language and Power: Relasi Bahasa, Kekuasaan, dan Ideologi. Malang: Boyan Publishing.

Iosifidis, P. (2011). The public sphere, social networks and public service media. Information, Communication \& Society, 14(5), 619-637.

Kalogeropoulos, A., Suiter, J., Udris, L., \& Eisenegger, M. (2019). News media trust and news consumption: Factors related to trust in news in 35 countries. International Journal of Communication, 13, 22.

Mahsun. (2007). Metode Penelitian Bahasa: Tahapan Strategi, Metode, dan Tekniknya. Edisi Revisi 3. Jakarta: Raja Grafindo Persada.

Schultz, T. (2000). Mass media and the concept of interactivity: an exploratory study of online forums and reader email. Media, culture \& society, 22(2), 205-221.

Sobur, A. (2006). Analisis Teks Media: Suatu Pengantar untuk Analisis Wacana, Analisis Semiotik, dan Analisis Framing. Bandung: Rema Rosdakarya.

Sultan. (2018). Membaca Kritis (Mengungkap Ideologi Teks dengan Pendekatan Literasi Kritis). Yogyakarta : BASKARA MEDIA.

Zakaria, F. (2019). Representasi Ideologi Feminisme Dalam Teks Artikel Media Online Tirto.Id Serta Pemanfaatannya Sebagai Buku Pengayaan Membaca Kritis. Thesis. Bandung: Prodi Pendidikan Bahasa Indonesia Sekolah Pascasarjana Universitas Pendidikan Indonesia. 